\title{
Practices and Therapeutic Strategies of the Psychosocial Care Centers Alcohol and Drugs ${ }^{1}$
}

\author{
Maria de Nazareth Rodrigues Malcher de Oliveira Silva², Gardênia da Silva Abbad², Lana Montezano² \\ ${ }^{2}$ Universidade de Brasília, Brasília-DF, Brazil
}

\begin{abstract}
Changes in drug policy have expanded community mental health services, such as the Psychosocial Care Centers Alcohol and Drugs and, consequently, the therapeutic practices and strategies of psychosocial care. This study aimed to describe the therapeutic practices and strategies of these services, based on documents and perceptions of practitioners, in the light of the psychosocial model. For this, a mixed method study was carried out in three services (two in the Federal District and one in São Paulo), data were collected in 48 government documents, 1,157 medical records, interviews with 23 practitioners, and in three focal groups that were treated using descriptive statistics and content analysis. 58 therapeutic practices and strategies were identified in government documents. In services, there is a predominance of individualized practices and few extramural activities, of social and intersectoral insertion, mainly due to problems of institutional infrastructure. The psychosocial care model has not been fully applied by the services due to several situational factors discussed in this study.
\end{abstract}

Keywords: psychosocial rehabilitation, therapies, psychosocial care center

\section{Práticas e Estratégias Terapêuticas dos Centros de Atenção Psicossocial Álcool e Drogas}

Resumo: Mudanças na política sobre drogas ampliaram serviços comunitários de saúde mental, como os Centros de Atenção Psicossocial Álcool e Drogas e, consequentemente, as práticas e estratégias terapêuticas de atenção psicossocial. Este estudo teve por objetivo descrever as práticas e estratégias terapêuticas destes serviços, a partir de documentos e percepções dos profissionais, à luz do modelo psicossocial. Para isso, realizou-se pesquisa de método misto em três serviços (dois no Distrito Federal e um em São Paulo), levantando dados em 48 documentos governamentais, em 1.157 prontuários, em entrevistas com 23 profissionais e em três grupos focais, que foram tratados utilizando estatística descritiva e análise de conteúdo. Foram identificadas 58 práticas e estratégias terapêuticas nos documentos governamentais. Nos serviços, há o predomínio de práticas individualizadas e poucas atividades extramuros, de inserção social e intersetoriais, devido principalmente a problemas de infraestrutura institucional. O modelo psicossocial de cuidado não tem sido integralmente aplicado pelos serviços devido a diversos fatores situacionais discutidos neste trabalho.

Palavras-chave: reabilitação psicossocial, terapêuticas, centro de atenção psicossocial

\section{Prácticas y Estrategias Terapéuticas de los Centros de Atención Psicosocial Alcohol y Drogas}

\begin{abstract}
Resumen: Cambios en la política sobre drogas ampliaron servicios comunitarios de salud mental, como los Centros de Atención Psicosocial Alcohol y Drogas y, consecuentemente, las prácticas y estrategias terapéuticas de atención psicosocial. Este estudio tuvo por objetivo describir las prácticas y estrategias terapéuticas de estos servicios, a partir de documentos y percepciones de los profesionales, a la luz del modelo psicosocial. Para ello, se realizó una investigación de método mixto en tres servicios (dos en el Distrito Federal y uno en São Paulo), levantando datos en 48 documentos gubernamentales, en 1.157 prontuarios, en entrevistas con 23 profesionales y en tres grupos focales, que fueron tratados utilizando estadística descriptiva y análisis de contenido. Se identificaron 58 prácticas y estrategias terapéuticas en los documentos gubernamentales. En los servicios, hay el predominio de prácticas individualizadas y pocas actividades extramuros, de inserción social e intersectoriales, debido principalmente a problemas de infraestructura institucional. El modelo psicosocial de cuidado no ha sido íntegramente aplicado por los servicios debido a diversos factores situacionales discutidos en este trabajo.
\end{abstract}

Palabras clave: rehabilitación psicosocial, terapias, centro de atención psicosocial

\footnotetext{
${ }^{1}$ Article derived from the doctoral thesis of the first author, under the supervision of the second, defended in 2016, in the Post-Graduate Program in Clinical Psychology and Culture of the Instituto de Psicologia da Universidade de Brasília. Support: Coordination for the Improvement of Higher Education Personnel (CAPES; Grant Call 024/2010).

Correspondence address: Maria de Nazareth Rodrigues Malcher de Oliveira Silva. Universidade de Brasília. Faculdade Ceilândia. Centro Metropolitano, Conjunto A, lote 01, Brasília-DF, Brazil. CEP: 70.910-900. E-mail: malchersilva@unb.br
}

The Unified Health System (Portuguese acronym: SUS) brought changes in the production of health care technologies with the use of territorial and contextual practices, and with the incentive for actions to promote health in the daily life of services.

In the case of the mental health area, the damages caused by the increase and problematic use of alcohol and 
other drugs generate complex care demands and investments in multifactorial therapeutic practices and strategies, in the search for effectiveness in the treatment, which happens through the psychosocial attention in substitutive services and strategies, such as territorial resources, the community and intersectoral network (Merhy \& Amaral, 2007; Pitta, 2011). For this, also influenced by diverse world experiences, the Brazilian government instituted, by means of Law n. 11,343, of 2006, the National System of Public Policies on Drugs (Portuguese acronym: SISNAD) and prescribes measures to prevent abuse, attention and social reintegration of drug users and addicts, among other measures; which became the legal framework for these changes (Ministério da Saúde, 2003).

The National Policy on Drugs has instituted a new approach based on the reduction of vulnerability and risk factors and the strengthening of protection through therapeutic practices and strategies of social insertion, harm reduction and intersectoral partnerships. To that end, investments in this area were necessary for the search for effective actions that consolidate the psychosocial care model (Ministério da Saúde, 2011, 2012).

In the SUS, both the Mental Health Policy and the National Drug Policy, new services emerged to replace the previous model of care of hospitalizations in psychiatric hospitals, especially the Psychosocial Care Centers Alcohol and Drugs (CAPS AD).

CAPS AD are recognized as specialized mental health services that act with clinical practices of psychosocial insertion in the territory, distinguishing themselves in their characterization, according to the size of the equipment, physical structure, professional diversities, therapeutic activities and specificity of the demand, such as: (1) CAPS I and CAPS II, for daily care of adults with mental disorders; (2) CAPS III, for short-term care; (3) CAPS i, for childhood and adolescence; and (4) CAPS AD, for users of alcohol and other drugs (Ministério da Saúde, 2003).

This study deals specifically with CAPS AD III, which is a population coverage service of 200 to 300 thousand inhabitants, from which longitudinal treatment of adults in problematic use of alcohol and other drugs is performed, with reception of the demands, organization of therapeutic plan and development of practices with the user and his / her family, primarily in collective spaces (Ministério da Saúde, 2011).

As of 2009, with the requirements of international and national organizations due to the concern with the advance of drugs, there was a need to adapt the Brazilian public services to the transformations in the care of people in problematic use of alcohol and other drugs. In this sense, in 2010, the Federal Government set as priority the confrontation, the prevention of drug use, with a substantial financial incentive, allocating R \$ 410 million of Brazilian Reais in intersectoral services (Ministério da Saúde, 2012).

Despite this context of relevance on the need for studies of the adoption of the new psychosocial model for the treatment of drug use, P.H.A. Costa, Mota, Paiva and Ronzani (2015) identified a shortage of studies in the literature on the drug care network and found the insufficiency and disintegration of the CAPS AD coverage in relation to existing demands, the need to review the role of the CAPS AD to allow its strengthening, expansion, improvements in its structure and the re-adaptation of the practices, besides the State to make feasible the strengthening of intersectoral actions, articulation of care and improvement of working conditions.

In the routine of the CAPS AD, even after the adoption of the psychosocial model, the old practices coexist with the new ones, and practitioners report difficulties in establishing interactions with the intersectoral network. Jucá, Lima and Nunes (2008) affirm that the care model, on the one hand, requires the use of complex practices, which include the analysis of contexts and the search for innumerable interactions and resources fundamental to care, on the other hand, governmental guidelines are not clear and need systematization.

In this study, the therapeutic practices adopted by the CAPS AD are defined as any care actions carried out in the daily services. Already the strategy can be understood as developing resources that make it possible to contextualize, in a way favorable to the understanding of the demands of the user and family, and, thus, to subsidize a more integrated service to the therapeutic practices. Therefore, therapeutic practices and strategies are developed by health professionals in their interactions with the person in treatment of the problematic use of alcohol and other drugs, family, community, intersectoral network and technical team, aiming at the provision of work in mental health, being based principles of science and government guidelines.

Therefore, the psychosocial model of care and the advances and investments that have occurred in recent years have led to the restructuring of work management, the understanding of multiple factors of users (biological, contextual and drug exposure) and the development of therapeutic practices and strategies in the routine of the CAPS AD to deal with the problem of drug progress and the damage caused by the problematic use regulated by the governmental guidelines (United Nations Office on Drugs and Crime [UNODC] \& World Health Organization [WHO], 2008).

Given the context presented, this study aimed to describe therapeutic practices and strategies based on documents and perceptions of practitioners, considering the psychosocial model. With this, we intend to understand the health technologies used in the CAPS AD and the necessary conditions for their effectiveness in the care of people in problematic use of alcohol and other drugs.

\section{Method}

This descriptive research with a mixed approach (qualitative and quantitative) was carried out in four stages: (1) study of government documents to survey the characterization and therapeutic practices and strategies of the CAPS AD standardized in the guidelines for caring for people in problematic use of alcohol and other drugs; (2) 
study from physical and electronic documents of the CAPS $\mathrm{AD}$ participants of the research, to describe the daily reality in three CAPS AD and identify the practices recorded in the medical records; (3) conducting semi-structured interviews with practitioners working in three CAPS AD to raise the practices performed in each category and to understand the individual perception about practices in the daily service; and (4) focus groups with the teams of these services, which help in the perception about the daily CAPS AD.

\section{Participants}

The study scenario was based on the three CAPS AD, one located in a municipality of the State of São Paulo (CAPS AD SP) and two in the Federal District (CAPS AD DF 1 and CAPS AD DF 2). These services were selected with the general criterion of being qualified by the Ministry of Health and, specifically, in the Federal District, for the inauguration time (oldest and newest), and, in São Paulo, for being a service of formative reference of the Brazil together with more than 21 treatment centers of different parts of the world (Ministério da Saúde, 2011).

These services are distinguished in relation to the population and territorial coverage, being that in the Federal District it is low in relation to the population index, whereas in São Paulo there is high coverage and it is considered a service of quality and effectiveness in the treatment of people with problems related to drug use.

Participants in the study were practitioners from the three scenarios selected for the study, of which 22 participated in the individual interviews and 23 of the focus groups (from six to eight participants per service), totaling 45 practitioners from several areas selected for convenience, who volunteered to participate in the primary data collection, accounting for $26.8 \%$ of the total number of people working in the CAPS AD study.

\section{Instruments}

Initially, a survey was conducted on national and international government Web sites, selecting documents using descriptors: mental health policy, alcohol and other drugs, psychosocial rehabilitation, therapeutic practices and strategies and CAPS that contained in the menu or abstract contents the subject of the study.

In this stage, 48 governmental norms and guidelines were selected, including ten legal norms (Laws, Decrees, Ordinances, Resolutions) and 38 manuals and technical reports on the psychosocial model, CAPS AD and therapeutic practices and strategies issued between 1995 and 2014, of which the following instruments were constructed: (1) a list of verifications with 58 practices and therapeutic strategies raised to collect descriptions of therapeutic practices adopted by practitioners in the treatments since the admission of the users, as recorded in the active medical records of the CAPS AD of the study; and (2) a script of similar content issues for the semi-structured interview and for the focus group.
All the instruments were submitted to two validation steps. The first stage of structuring was carried out by a research group of a federal public university and evaluated the representativeness of the content of the items, the precision of the language and the format of the scripts. This step resulted in the creation of a glossary defining the terms of the checklist to increase the accuracy of the information, such as support during the interview and the focus group between the researcher and the practitioners. The second validation of semantics occurred with six practitioners from a CAPS AD of the Federal District, in which synonyms of the denominations were included.

The instrument for semi-structured interviews was organized into 13 closed questions (twelve on daily work and one on the list of verifications of the 48 practices and strategies developed by the practitioner) and five open questions (one on daily services and four on practices in relation to those that are performed in the service and considered effective, that happen and should be improved, that should occur, as well as the conditions of the service for its accomplishment). The open interview questions were also used in the focus group.

\section{Procedures}

Data collection. The checklist was used to identify the therapeutic practices and strategies developed in the CAPS $\mathrm{AD}$, using 773 medical records of the DF 1, 211 of DF 2, and 173 of SP, totaling a sample of 1,157 medical records, not considering recurrence in the same medical record.

The interviews were scheduled according to the availability of the practitioners and occurred in three moments: (1) presentation of the objective of the study and interview script; (2) individual self-comprehension of closed questions; and (3) application of the open questions, with full recording.

The focus groups were held in each CAPS AD for two hours each with the invited practitioners, who discussed the same open questions as the interview instrument. The group was carried out in five stages: (1) presentation of the study and stages of the focus group; (2) individual distribution and completion of the open questions of the instrument; (3) organization of subgroups and random distribution of instruments completed in the previous stage, aiming at the discussion of responses and reorganization of consensuses in a single form; (4) presentation of the consensual responses of each subgroup to the other participants; and (5) discussion in plenary to construct a final document containing the consensual responses to the items in the script.

Data analysis. The data collected with the checklist were treated with descriptive statistics, accounting for the frequencies of the therapeutic practices and strategies of the medical records. The recordings of the interviews and the fifth stage of the focus groups were fully transcribed and subjected to a variation of categorical content analysis (Bardin, 2011).

Data processing was performed in the following steps: (1) organization in a single file with participants' responses 
to interviews and focus groups, to construct the corpus for analysis; (2) realization of a floating reading workshop and survey of content categories with the authors' research group; (3) reorganization of the corpus, from the content units defined in the previous stage; (4) constitutive definition of categories and organization of responses according to categories; and (5) identification of the speeches and frequency of the most representative evocations of each theme.

\section{Ethical Considerations}

The study followed the parameters of guidelines and regulatory norms of research with human beings of the National Health Council, Resolution 466/2012 (Ministry of Health, 2013). Obtained approval number 551,779 by the Ethics and Research Committee of the Faculty of Health of the University of Brasília (CEP/FS/UnB).

The primary data collections were recorded with the prior consent of the participant, through the Free Informed Consent Form (FICF).

\section{Results}

The results of the study deal with the analysis and triangulation in several instruments used in the research: (1) study based 48 governmental documents, among 13 (27\%) international, 32 (67\%) national and $3(7 \%)$ district; (2) verification of the 58 practices and therapeutic strategies selected in government documents in 1,157 medical records; and (3) interviews with 45 practitioners from all categories of service teams, with a female prevalence, a statutory regime, a 40-hour workweek and a duration of work in the CAPS $\mathrm{AD}$ of the study between 3 and 4 years, highlighting that in the CAPS AD SP the workers are predominantly employees whose duties and rights are provided for in the Consolidation of Labor Laws (94,7\%).

Governmental documents present a diversity about mental health and drug use, influenced by the inclusion of this issue as a public health problem in national and international governmental agendas. Frequent themes were: (1) profile of drug use and its associated vulnerabilities; (2) description of the dependency and its complex multifactorial interaction; (3) guidelines for the development of prevention, intervention and authority actions; (4) definition of the psychosocial care network for care in services; (5) description of the structure and operation of the services; (6) description of therapeutic practices and strategies of the psychosocial model; and (7) reports on the service, practitioners and their respective practices.

In an international document, nine guidelines are presented for the care of people in abusive use of alcohol and other drugs, such as: (1) availability and access to treatment of drug addiction; (2) screening, assessment and diagnosis; (3) disclosure of treatment information; (4) the treatment of drug addiction, based on respect for human rights and the dignity of the patient; (5) the provision of specific conditions of care for special subgroups; (6) the opportunity to treat drug users within the criminal justice system; (7) community involvement in patient care and orientation; (8) the clinical management of drug dependency services; and (9) treatment systems with various equipment and resources. In addition to these principles, the guidelines recommend that care should consider the individual, the substance used and the context of the use, and that the routines be interdisciplinary and multiprofessional, encompass the territory and seek the social insertion of the user (UNODC \& WHO, 2008).

These guidelines recommend the guarantee of a therapeutic alliance between the practitioner and the user for adherence and quality of treatment; the joint intervention, pharmacological and psychosocial, that is not limited only in the symptom of addiction, but in the multifactorial understanding, through effective practical means; and the systematic registration of the practices developed for the production of scientific evidences about its effectiveness that subsidize the improvement of the model of psychosocial attention in benefit to the user, the quality of the care and the improvement of the services.

Health practices are referred to in government documents as low-demand technologies that aim at adapting services to users' needs and include administrative activities such as accommodation of schedules, receptionand dispensing of health protection inputs (Ministério da Saúde, 2011). The Ministry of Health (2002), in Ordinance No. 336, dated February 19, 2002, describes how humanized therapeutic practices, organized by the Unique Therapeutic Project (Portuguese acronym: PTS) based on clinical criteria (detoxification, abstinence, psychiatric and clinical comorbidity) and psychosocial (conflict management, job insertion, vocational and legal) for recovery, harm reduction and social and occupational insertion of people with problematic use of alcohol and other drugs.

In addition to these, government documents cite as good therapeutic practices: psychotherapy (by cognitive behavioral method), motivational interview, case management, self-help groups, socio-cultural, vocational and employment activities, legal counseling and social support with intersectoral actions with other services and policies ("Crack, é possível vencer", 2011; Ministério da Saúde, 2011; UNODC \& WHO, 2008).

The survey of 58 therapeutic practices and strategies in the 1,157 medical records showed a diversity in each study service, confluent with the results of the interviews and the focus group in five categories of content extracted and their respective frequencies of evocations: (1) "Assessment of the functioning and the therapeutic practices of the CAPS AD" with 147 evocations; (2) "Relationship with the community" with 15 evocations; (3) "Intersectoral Network" with 22 evocations; (4) "Infrastructure" with 69 evocations; and (5) "Access to CAPS AD" with 16 evocations.

\section{Assessment of the Functioning and Therapeutic Practices of the CAPS AD}

The necessary information on the evolution of the treatment in the medical records, in general, were incomplete 
or absent, and the patient did not sign the consent form. The Unique Therapeutic Projects (PTS) and the interdisciplinary therapeutic practices and strategies are little registered in all the CAPS AD studied. In the CAPS AD DF 1, group activities are recorded in minute books that describe the type of group, the dynamics used and the number of participating users.

The therapeutic practices and strategies are indicated in government documents focused on the demands of the users and carried out with interdisciplinary knowledge by the teams (Ministério da Saúde, 2012; UNODC \& WHO, 2008). However, the CAPS AD present a predefined weekly schedule of therapeutic practices, regardless of the users' demands, with group activities, with lack or absence of external activities. For practitioners, the organization of weekly activities of the CAPS AD is considered a major challenge because of: (1) the complexity of treatment for the problematic use of alcohol and other drugs, which necessarily involves actively seeking relationships with the community and the Psychosocial Care Networks (Portuguese acronym: RAPS) to enable external service activities, carried out in the territories; and (2) inadequate working and infrastructure conditions.

The survey of 58 therapeutic practices and strategies in the medical records presented a frequency of individual consultations by nursing technicians (523), psychiatrists (376), psychologists (372) and nurses (312). In addition to these, records of group visits were also found (327). In the DF services, the services are predominantly individual outpatient clinics, psychology and psychiatry, while in the CAPS AD $\mathrm{SP}$, there is an everyday practice in the territories, with the practitioners that make up the RAPS. These practitioners are still central elements in the accountability of the attendance of diverse demands of the users, such as: solicitation of social benefits, change of prescription of medicine, administrative discharge, admission for brief hospitalization, among others.
It is observed that 31 therapeutic practices and strategies were not recorded in the medical records. Practitioners describe therapeutic practices and strategies from three different perspectives: (1) fifteen are practiced and considered effective for the space of exchange, rebalancing of the mind, promotion of the quality of life and active participation of the patient in collective activities (team meeting, assembly, integral welcome, groups, matrix-based strategy, physical activity, harm reduction, reference technician, psychopharmacology, nocturnal hospitality, protocols of care, PTS, individual care); (2) eight are carried out, but they need to be improved (day and full day care, family group, PTS, assembly, groups, individual care, active search, income generating activity); and (3) ten do not occur in the CAPS AD due to insufficiency in meeting users' expectations and demands, which often require joint actions by multi-professional teams and RAPS, but are considered desirable to provide a quality service to the user (activities in the territory of production and income generation cooperatives, articulation with the network, vocational and non-vocational courses, association of relatives, questionnaires and evaluations, epidemiological profile, income generation, matrix-based strategy, foster care).

Practitioners point out that the difficulty in responding to the demands of users and their families entails more bonding with secondary benefits (work permits, retirement pensions, social benefits) than with the therapeutic plan and psychosocial activities, influencing the quality of care. Thus, they suggest that these practices be monitored, monitored and evaluated constantly.

Table 1 presents the quantitative records of the ten most adopted practices in each CAPS AD, according to the medical records and considering their recidivism. In the first line the number of the sample of medical records analyzed in each service is analyzed.

Table 1 - Therapeutic practices and strategies most used in the CAPS AD recorded in medical records Most Used Therapeutic Practices and Strategies in Psychosocial Care Centers Alcohol and Drugs

\begin{tabular}{|c|c|c|c|c|c|c|}
\hline \multirow{2}{*}{ Order } & \multicolumn{2}{|l|}{$\begin{array}{l}\text { CAPS AD DF } 1 \\
\quad(n=773)\end{array}$} & \multicolumn{2}{|l|}{$\begin{array}{l}\text { CAPS AD DF } 2 \\
(n=211)\end{array}$} & \multicolumn{2}{|l|}{$\begin{array}{l}\text { CAPS AD SP } \\
\quad(n=173)\end{array}$} \\
\hline & Strategy /Practice & $\left(f_{a}\right)^{*}$ & Strategy / Practice & $\left(f_{a}\right)^{*}$ & Strategy / Practice & $\left(f_{a}\right)^{*}$ \\
\hline $1^{\mathrm{o}}$ & Pharmacotherapy & 1.479 & Nursing Technical Care & 523 & Welcome & 65 \\
\hline $2^{\circ}$ & Psychiatric Care & 1.384 & Psychiatric Care & 376 & Group Care & 65 \\
\hline $3^{\circ}$ & Clinical care & 933 & Psychology Care & 372 & Unique Therapeutic Project & 44 \\
\hline $4^{\circ}$ & Nursing Care & 807 & Group Care & 327 & Psychiatric Care & 36 \\
\hline $5^{\circ}$ & Nursing Technical Care & 779 & Nursing Care & 312 & Psychotherapy & 34 \\
\hline $6^{\circ}$ & Welcome & 695 & Pharmacotherapy & 290 & Nursing Care & 32 \\
\hline $7^{\circ}$ & Group Care & 622 & Technician of Reference & 289 & Medication Administration & 25 \\
\hline $8^{\circ}$ & Individual Care & 508 & Individual Care & 254 & Detoxification & 21 \\
\hline $9^{\circ}$ & Previous Story & 407 & Occupational Therapy Care & 157 & Term of Acceptance to Treatment & 17 \\
\hline $10^{\circ}$ & Initial Assessment & 393 & Welcome & 138 & Therapeutic Workshop & 16 \\
\hline
\end{tabular}

Note. ${ }^{*}$ Count with recidivism use in the medical record 
It is observed that only four practices (psychiatric care, nursing care, foster care and group care) are adopted in the three CAPS AD studied and occur in different orders. This variation of practices was also confirmed by the practitioners' perception in interviews and focus groups.

In the CAPS AD of the DF, the frequencies of the first five practices found in the medical records are of specific care of professional category and typical of the biomedical clinical field, observed in two situations: (1) medicine therapy, centered in the medical category, and when the user is hospitalized, being followed directly by the doctor and nursing team; and (2) care by professional category, in a systematic and evolutionary way in the medical records sent by the courts in compliance with the penalty, with clinical data, recorded by the doctor and the psychologist, in the form of follow-up reports. The medical records are still prevalent in the medical category. This practitioner is still a central element in the accountability of users' demands, such as requesting social benefits, change of prescription of medicine, administrative discharge, admission for brief hospitalization, among others.

\section{Relationship with the Community and Intersectoral Network}

The CAPS AD of DF and SP presented a distinction between them in relation to the predominance of intersectoral and extra CAPS activities. The CAPS AD SP presented a daily of twelve practices and therapeutic strategies found in the medical records of this service, in which eight are of psychosocial attention, such as the participation of users in solidarity economy projects and community activities. In the CAPS AD DF there is a predominance of individual care practices occurring in these units performed by one professional at a time.

According to the perception of practitioners of these services, users should participate in more extra CAPS activities. CAPS AD SP, despite applying fewer therapeutic practices and strategies (20), seems to be adopting more broadly the network model of psychosocial care in meeting the demands of users. Evidence of the effectiveness of these psychosocial practices conducted in groups and territories by multi-professional teams, as suggested by government guidelines, would be recommendable and compared with evidence of the results of the traditional practices of individual care, still dominant in the two CAPS DF. Thus, it would be possible to assess the users' adherence to the treatment and the impacts of these practices on the health and social reintegration of the user.

The psychosocial practices presented low expression in the medical records, even though they are referred by the practitioners as important therapeutic strategies for the social insertion of the users. In the CAPS AD of the DF these therapeutic practices occupied 6th place in DF 1 and 7th place in DF 2, while in the CAPS AD SP they are among the first three categories most used by practitioners in the service to users. For practitioners, activities with the intersectoral services network are important practices for the social insertion of patients with the primary support network and with the labor market. However, they do not yet adopt these practices fully, due to the lack of knowledge about access and operation of the network, problems of territorial and service infrastructure, lack or deficiency of user insertion support networks, absence of transportation to mobility of the team, difficulty in articulating practitioners with the intersectoral network, and poor identification of the CAPS AD practitioner with the mental health area.

Interviewees reported that the neighboring community seems to be unaware of the goals and functions of the CAPS AD or not accept daily contact with users. For practitioners, the solution to this problem would be through community awareness activities to the work developed by these services, through charity bazaars, celebrations in festive dates, home visits, groups with relatives and assemblies.

\section{Infrastructure and Access to CAPS AD}

Regarding the working conditions, the interviewees referred to the difficulties of elaborating the service scales that occur due to insufficient staffing and different working hours (20, 30 and 40 hours a week), prejudicing the scheduling and offer of therapeutic practices and strategies to the user and family members. This situation is aggravated when there are practitioners on vacation or on work permit.

In the evocations of the interviewees regarding infrastructure, problems related to the physical structure of the CAPS AD were mentioned (small spaces incompatible with the service, absence of environments suitable for activities outside the building, scarcity or lack of material resources, such as: lack of transportation of the service (car, ambulance) and supplies for workshops; insufficient human resources (small team in relation to workload, lack of some professional categories, making it impossible to compose multi-professional teams needed to meet users' demands).

The participants affirmed that these infrastructure problems directly affect the daily life of the services, making it difficult to manage the services, perform some therapeutic practices, access and mobility of the user and the practitioners in carrying out external practices and in the release and distribution of materials for the realization of workshops and other activities. Practitioners have reported that the material released by the Secretariat of Health for the CAPS AD frequently does not correspond to the real needs of the services and that, therefore, practitioners need to improvise or seek strategies to raise funds to acquire the necessary materials.

\section{Discussion}

The research of therapeutic practices and strategies from governmental documents and practitioner perceptions, in the light of the psychosocial model, made it possible to understand the routine and the problematic aspects that hinder the effectiveness of the psychosocial care model. 
Advances from the overcoming of the mental hospital model, the psychiatric reform, the creation of substitutive services and the innovative design of a model of mental health care for the problematic use of alcohol and other drugs are still in the process of consolidation in the daily services, constituting as challenges to overcome regarding the quality of service, user safety and policy effectiveness.

The diversity of therapeutic practices and strategies found in government documents indicates multiple possibilities and new ways of producing health, according to the psychosocial care model. However, this variety of practices seems to be generating misunderstandings and making it difficult to systematize the routines and the dynamics of services. The results of this research evidenced that the CAPS AD adopt practices that are poorly systematized and still far from the standards established by government policies, with a predominance of individual care, absence or lack of extra CAPS activities, and with unsatisfactory results, such as the low level of user adherence to treatments (P.H.A. Costa, Colugnati, \& Ronzani 2015; Leal \& Antoni, 2013; Ministério da Saúde, 2003; Vasconcelos, Jorge, Catrib, Bezerra, \& Franco, 2016).

The organization and registration of therapeutic practices and strategies performed by the CAPS AD are fragile, incomplete and illegible, reduced to medical follow-up and distant from the psychosocial approach, without concern for the constitution of evidences on the development and improvement of therapeutic practices (Conselho Federal de Psicologia, 2011).

Traditional strategies such as psychopathological signs, focus on addiction, therapeutic interventions based on medicines and internal for the search for remission of withdrawal symptoms or resulting from a decrease in alcohol consumption prevail in the CAPS AD daily, mainly in the Federal District. Few therapeutic strategies were found aimed at harm reduction, recovery and, mainly, the social insertion of users. In addition, they contradict the governmental directives, which cite as good practices the territorial monitoring, the matrix-based strategy, the home care, the intersectoral work and the register of discharge of the user (Ministerio da Saúde, 2012; UNODC \& WHO, 2008).

In the CAPS AD studied, several forms of care are offered to users with problems of abusive consumption of alcohol and other drugs. It was observed the predominance of therapeutic actions occurring primarily in these units, in which the patient is attended according to a predefined schedule of individual care with little or no opportunity to participate in extramural and intersectoral therapeutic activities, which have been used mainly by the CAPS AD of São Paulo. The adoption of the psychosocial model of care requires the implementation of social reinsertion activities that need to be practiced by practitioners in interaction with the intersectoral network. The CAPS AD SP adopt more extramural practices of social reintegration and less variety of intramural therapeutic practices than the CAPS of the DF. However, no service seems to be adopting the psychosocial model in its entirety. According to the medical records, both the DF and SP services registered high levels of drop-out and little information about the causes of non-adherence of users to treatment.

The contextual issues described by the CAPS AD practitioners indicate working conditions that are not conducive to the full adoption of the psychosocial model. The results of this research point to the need for greater investments in improving working conditions and improving the practices of entry and assignment of servers in the CAPS $\mathrm{AD}$, as verified by other studies (P.H.A. Costa, Mota, et al., 2015; Leite, Rocha, \& Santos, 2018; Lima, Lima, \& Marques, 2017; Vasconcelos et al., 2016).

Some authors affirm that these practices of social insertion, even being considered pillars of support of the psychosocial model, involve coping with numerous challenges to overcome the various fragility points inherent to the contexts of the CAPS AD, among which the following stand out: lack or absence of the RAPS and the lack of physical infrastructure and working conditions in the services, which has triggered problems of daily operation of these units, such as: scarcity of materials, little variety of activities, inadequate facilities for group activities, irregular medicine supply, adoption of traditional practices such as the resumption of compulsory hospitalizations and old models of treatment and nonfulfillment of the specific demands of the user. These unfavorable conditions of functioning are probably associated with the drop-out cases, to the cases of relapse, as well as to the suffering and sickness of the practitioners that work in these services (Clementino et al., 2016; Conselho Federal de Psicologia, 2011; P.H.A. Costa, Colugnati, et al., 2015; P.H.A. Costa, Mota, et al., 2015; Leal \& Antoni, 2013).

The difficulty of the CAPS AD to fit and seek solutions to make feasible the psychosocial model of SUS guidelines and Mental Health Policy can be verified in this research and confirms the challenge of developing representative practices, access to the user and efficient resources with better assistance results and guarantee of human rights (Clementino et al., 2016; M.M. Costa \& Dimenstein, 2015; P.H.A. Costa, Mota, et al., 2015; Leal \& Antoni, 2013; Ventura, Jorge, \& Moll, 2014).

It is important to highlight in the theoretical studies by Lima and Schneider (2013) the absence of specific research in the CAPS AD. In addition, empirical studies (Clementino et al., 2016; Leal \& Antoni, 2013; Marques \& Egry, 2011; Ventura et al., 2014) show user opinion surveys on isolated therapeutic activities with low scientific evidence of effectiveness good practices, the objective effects of therapeutic interventions on health indicators and social inclusion of the user, nor on levels of adherence to treatment.

The practitioners of the study were in favor of a model of participative management of the services and expect an organizational dynamic with well-defined routines, systematization of practices carried out, generation of evidences about the epidemiological profile of the user and about the efficiency and effectiveness of the therapeutic practices and strategies adopted. However, various problems make it difficult to promote such improvements. National and international guidelines (Ministério da Saúde, 2011, 
2012; "Saúde Mental em Dados", 2012; UNODC \& WHO, 2008) confirm these needs so that it is possible to constitute evidences of these practices, by means of control systems for recording user information and the routine of the service; or even invest in systematic studies of the effectiveness of the practices and daily life of the CAPS AD for a science of evidences that consolidate the psychosocial model.

His study contributed to the survey of the therapeutic practices and strategies described in government documents and developed in the reality of the CAPS AD, according to the practitioners' perception. It also allowed the diagnosis of infrastructure problems and institutional support to the full application of the psychosocial model that will need to be improved for safety and user insertion and quality of service, reducing the evasion and suffering of practitioners. In addition, the findings are reliable, insofar as they describe the current profile of three services, from various sources of information, methods of data collection, triangulation and interpretive synthesis, with the participation of judges.

The results of this research showed that services are still in the process of implementing the psychosocial care model instituted by the government guidelines and the absence of procedures for follow-up, monitoring and assessment the context, users and family and services provided.

The limitations of this study were the coverage of a representative sample of the CAPS AD in Brazil, and it was not possible to generalize directly the results; the accuracy of the data collected, due to the fact that it cannot state whether the practices were actually carried out or if there was negligence in the registration in the services documents; and the assessment as to the qualification of the practices are appropriate or not by the indication of the practitioners' perception, necessitating a more objective investigation as to the effectiveness of each practice.

Future research with a representative sample of the CAPS $\mathrm{AD}$ is suggested to increase the external validity of the results of this study, improve the diagnosis and indicate additional ways to overcome the challenges to the institutionalization of the psychosocial model. Studies are also needed to enable the construction of measures to follow-up, monitor and assess the efficiency, efficacy (adherence to treatment) and effectiveness (user safety, social reintegration, health promotion and quality of life) to progressively establish a science of evidence.

\section{References}

Bardin, L. (2011). Análise de conteúdo [Content analysis] (L.A. Reto \& A. Pinheiro, Trans.). São Paulo, SP: Edições 70.

Clementino, F. S., Miranda, F. A. N., Martiniano, C. S., Marcolino, E. C., Pessoa Junior, J. M., \& Dias, J. A. (2016). Avaliação de estrutura organizacional dos Centros de Atenção Psicossocial do Município de Campina Grande, Paraíba [Assessment of organizational structure of Centers for Psychosocial Care in the City of Campina Grande, Paraíba State]. Revista Brasileira de Ciências da Saúde, 20(4), 261-268. doi:10.4034/RBCS.2016.20.04.01
Conselho Federal de Psicologia. (2011). Contribuições do Conselho Federal de Psicologia para a constituição da Rede de Atenção Psicossocial no Sistema Único de Saúde a partir do decreto 7.508/2011. Brasília, DF: CFP.

Costa, M. M., \& Dimenstein, M. (2015). CAPS com gerência pública e privada: Estudo na rede de atenção psicossocial do Rio Grande do Norte [CAPS with public and private management: Study in psychosocial care network of Rio Grande do Norte]. Revista de Psicologia, 6(1), 7-18. Retrieved from http://www.periodicos.ufc.br/psicologiaufc/ article/view/1689/1480

Costa, P. H. A., Colugnati, F. A. B., \& Ronzani, T. M. (2015). Avaliação de serviços em saúde mental no Brasil: Revisão sistemática da literatura [Mental health services assessment in Brazil: Systematic literature review]. Ciência \& Saúde Coletiva, 20(10), 3243-3253. doi:10.1590/1413-812320152010.14612014

Costa, P. H. A., Mota, D. C. B., Paiva, F. S., \& Ronzani, T. M. (2015). Desatando a trama das redes assistenciais sobre drogas: Uma revisão narrativa da literatura [Unravelling the skein of care networks on drugs: A narrative review of the literature]. Ciência \& Saúde Coletiva, 20(2), 395406. doi:10.1590/1413-81232015202.20682013

Crack, é possivel vencer: Enfrentar o crack. Compromisso de todos. (2011). Brasília, DF: Presidência da República.

Jucá, V., Lima, M., \& Nunes, M. O. (2008). A (re) invenção de tecnologias no contexto dos centros de atenção psicossocial: Recepção e atividades grupais [The (re) invention of technologies within the context of psychosocial care centers: Reception and group activities]. Mental, 6(11), 125-143. Retrieved from http://pepsic.bvsalud.org/scielo.php? script $=$ sci arttext\&pid=S1679-44272008000200008

Leal, B. M., \& Antoni, C. (2013). Os Centros de Atenção Psicossocial (CAPS): estruturação, interdisciplinaridade e intersetorialidade [The Psychosocial Care Centers (CAPS): Structuration, interdisciplinary and intersetoriality]. Aletheia, (40), 87-101. Retrieved from http://pepsic.bvsalud.org/scielo.php?script=sci arttext\&pid $=$ S1413-03942013000100008

Lima, F. C, \& Schneider, D. R. (2013). Avaliação dos Centros de Atenção Psicossocial: uma revisão integrativa da literatura nacional. [Evaluation of psychosocial care centers: an integrative review of the national literature]. Revista Caminhos On-line "Humanidades", 4(6), 39-64.

Costa, P. H A., Colugnati, F. A. B., \& Ronzani, T. M. (2015). Avaliação de serviços em saúde mental no Brasil: revisão sistemática da literatura [Evaluation of mental health services in Brazil: a systematic review of the literature\}. Ciência \& Saúde Coletiva, 20(10), 3243-3253. https://dx.doi.org/10.1590/1413-812320152010.14612014 
Leite, L. S., Rocha, K. B., \& Santos, L. M. (2018). A tessitura dos encontros da rede de atenção psicossocial. Trabalho, Educação e Saúde, 16(1), 183-200. doi:10.1590/19817746-sol00101

Lima, I. C. S., Lima, S. B. A., \& Marques, A. D. B. (2017). Desafios e avanços do processo de gestão de um centro de atenção psicossocial de um município do interior do nordeste brasileiro. Revista de Pesquisa: Cuidado é Fundamental online, 9(2), 408-415. doi:10.9789/21755361.2017.v9i2.408-415

Marques, C. M. S., \& Egry, E. Y. (2011). As competências profissionais em saúde e as políticas ministeriais [The competencies of health professionals and the ministerial policies]. Revista da Escola de Enfermagem da USP, 45(1), 187-193. doi:10.1590/S0080-62342011000100026

Merhy, E., \& Amaral, H. (2007). A reforma psiquiátrica no cotidiano II [Psychiatric reform in everyday life II]. São Paulo, SP: Aderaldo \& Rothschild.

Ministério da Saúde. (2002, 20 de fevereiro). Portaria No. 336, de 19 de fevereiro de 2002. Dispõe sobre os Centros de Atenção Psicossocial - CAPS, para atendimento público em saúde mental, isto é, pacientes com transtornos mentais severos e persistentes em sua área territorial, em regime de tratamento intensivo, semi-intensivo e nãointensivo. Diário Oficial da União, seção 1.

Ministério da Saúde. (2012, 27 de janeiro). Portaria No. 130, de 26 de janeiro de 2012. Redefine o Centro de Atenção Psicossocial de Álcool e outras Drogas 24 h (CAPS AD III) e os respectivos incentivos financeiros. Diário Oficial da União, seção 1.

Ministério da Saúde. (2012). Saúde Mental em Dados: Informativo Eletrônico, . Brasília, DF: Ministério da Saúde. Secretaria de Atenção à Saúde Departamento de Ações Programáticas Estratégicas. Coordenação Geral de Saúde Mental, Álcool e outras Drogas. 7(10). Retrieved from https://saudeecosol. files.wordpress.com/2012/03/saude-mental-em-dados10-ms.pdf

Ministério da Saúde. Conselho Nacional de Saúde. (2013, 13 de junho). Resolução $\mathrm{N}^{\circ} 466$, de 12 de dezembro de 2012. Aprova as diretrizes e normas regulamentadoras de pesquisas envolvendo seres humanos. Diário Oficial da União, seção 1.

Ministério da Saúde. Secretaria de Atenção à Saúde. CoordenaçãoGeral de Saúde Mental, Álcool e Outras Drogas. (2011). Saúde mental no SUS: As novas fronteiras da reforma psiquiátrica. Relatório de gestão 2007-2010. Brasília, DF: Ministério da Saúde.

Ministério da Saúde. Secretaria Executiva. Coordenação Nacional de DST/Aids. (2003). A política do Ministério da Saúde para atenção integral a usuários de álcool e outras drogas Brasília, DF: Ministério da Saúde.
Pitta, A. M. F. (2011). Um balanço da reforma psiquiátrica brasileira: Instituições, atores e políticas [An assessment of Brazilian psychiatric reform: Institutions, actors and policies]. Ciência \& Saúde Coletiva, 16(12), 4579-4589. doi:10.1590/S1413-81232011001300002

United Nations Office on Drugs and Crime \& World Health Organization. (2008). Principles of drug dependence treatment. Retrieved from https://www.unodc.org/ documents/drug-treatment/UNODC-WHO-Principlesof-Drug-Dependence-Treatment-March08.pdf

Vasconcelos, M. G. F., Jorge, M. S. B., Catrib, A. M. F., Bezerra, I. C., \& Franco, T. B. (2016). Projeto terapêutico em saúde mental: Práticas e processos nas dimensões constituintes da atenção psicossocial. Interface Comunicação, Saúde, Educação, 20(57), 313-323. doi:10.1590/1807-57622015.0231

Ventura, C. A. A., Jorge, M. S., \& Moll, M. F. (2014). Análise das dimensões organizacionais do Centro de Atenção Psicossocial [Analysis of the organizational dimensions of a Counseling and Psychological Service]. Journal of Nursing and Health, 4(1), 4-14. doi:10.15210/JONAH.V4I1.3937

Maria de Nazareth Rodrigues Malcher de Oliveira Silva is a Professor of the Faculdade de Ceilândia of the Universidade de Brasília, Brasília-DF, Brazil.

Gardênia da Silva Abbad is a Professor of the Instituto de Psicologia of the Universidade de Brasília, Brasília-DF, Brazil.

Lana Montezano is a Ph.D candidate of the Faculdade de Economia, Administração, Contabilidade e Gestão de Políticas Públicas of the Universidade de Brasília, Brasília-DF, Brazil.

\section{Authors' Contribution:}

All authors made substantial contributions to the conception and design of this study, to data analysis and interpretation, and to the manuscript revision and approval of the final version. All the authors assume public responsability for content of the manuscript.

Received: Apr.13, 2017

1st Revision: Jul .05, 2017

2nd Revision: Oct. 23, 2017

3rd Revision: Jan. 08, 2018

Approved: Jan.29, 2018

How to cite this article:

Silva, M. N. R. M. O., Abbad, G. S., \& Montezano, L. (2019). Practices and therapeutic strategies of the psychosocial care centers alcohol and drugs. Paidéia (Ribeirão Preto), 29, e2903. doi: http://dx.doi.org/10.1590/1982-4327e2903 